\title{
Measurements of sulfur dioxide, ozone and ammonia concentrations in Asia, Africa, and South America using passive samplers
}

Gregory R. Carmichael ${ }^{\mathrm{a}, *}$, Martin Ferm $^{\mathrm{b}}$, Narisara Thongboonchoo ${ }^{\mathrm{a}}$, JungHun Woo a , L.Y. Chan ${ }^{c}$, Kentaro Murano ${ }^{\text {d }}$, Pham Hung Viet ${ }^{\mathrm{e}}$, Carl Mossberg ${ }^{\mathrm{f}}$, Rajasekhlar Bala ${ }^{\mathrm{g}}$, Jariya Boonjawat ${ }^{\mathrm{h}}$, Pramote Upatum $^{\mathrm{i}}$, Manju Mohan ${ }^{\mathrm{j}}$, Sharad P. Adhikary ${ }^{k}$, Arun B. Shrestha ${ }^{1}$, J.J. Pienaar ${ }^{\mathrm{m}}$, Ernst B. Brunke ${ }^{\mathrm{n}}$, Tai Chen ${ }^{\mathrm{o}}$, Tang Jie $^{\mathrm{p}}$, Ding Guoan ${ }^{\mathrm{q}}$, Leong Chow Peng ${ }^{\mathrm{r}}$, Sri Dhiharto ${ }^{\mathrm{s}}$, Hery Harjanto ${ }^{\mathrm{t}}$, Aida M. Jose ${ }^{\mathrm{u}}$, Wilson Kimani ${ }^{\mathrm{v}}$, Abdelmalek Kirouane ${ }^{\mathrm{w}}$, Jean-Pierre Lacaux ${ }^{\mathrm{x}}$, Sandrine Richard ${ }^{\mathrm{y}}$, Osvaldo Barturen ${ }^{\mathrm{z}}$, Jorge Carrasco Cerda ${ }^{\text {aa }}$, Augusto Athayde ${ }^{\mathrm{ab}}$, Tania Tavares ${ }^{\mathrm{ac}}$, Jose Silva Cotrina ${ }^{\mathrm{ad}}$, Erdal Bilici ${ }^{\mathrm{ae}}$

${ }^{a}$ Department of Chemical and Biochemical Engineering, Center for Global \& Regional Environmental Research, The University of Iowa, Iowa City, IA 52240, USA

${ }^{\mathrm{b}}$ IVL Swedish Environment Research Institute, Sweden

${ }^{\mathrm{c}}$ Department of Civil and Structural Engineering, Hong Kong Polytechnic University, Hung Hom, Kowloon, Hong Kong

${ }^{\mathrm{d}}$ National Institute for Environmental Studies, 16-2 Onogawa, Tsukuba-Shi, Ibaraki 305-0053, Japan

${ }^{\mathrm{e}}$ Department of Chemical and Environmental Engineering (CEED), Environmental Chemistry and Environmental Monitoring, Center of Environmental Chemistry(CECT), Vietnam National University, T3 Building, 90 Nguyen Trai, Hanoi, Viet Nam

${ }^{\mathrm{f}}$ Clo ISO/Swedforest, P.O. Box 4298, Vientiane, Lao PDR, Viet Nam

${ }^{\mathrm{g}}$ Department of Chemical and Environmental Engineering, The National University of Singapore, 10 Kent Ridge Cresent, Singapore 119260, Singapore

${ }^{\mathrm{h}}$ SEA START RC, Institute of Environmental Research, Chulalongkorn University, Phayathai Road, Bangkok 10330, Thailand

${ }^{\mathrm{i}} 16 / 7$ Moo 8, Tumbol Sunkamphang, Amphor Sankamphang, Chiang Mai 50130, Thailand

${ }^{\mathrm{j}}$ Center for Atmospheric Sciences, India Institute of Technology, Hauz Khas, New Delhi 110 016, India

${ }^{\mathrm{k}}$ Himalayan Climate Center, P.O. Box 10872, Kathmandu, Nepal

${ }^{1}$ Department of Hydrology and Meteorology, P.O. Box 406, Babar Mahal, Kathmandu, Nepal

${ }^{\mathrm{m}}$ School of Chemistry \& Biochemistry, Potchefstroom University, Potchefstroom 2520, South Africa

${ }^{\mathrm{n}}$ South African Weather Bureau, CSIR, P.O. Box 320, STELLENBOSCH 7599, South Africa

${ }^{\circ}$ Institute of Earth Sciences, Academia Sinica, P.O. Box 1-55, Nankang, Taipei 11529, Taiwan

${ }^{\mathrm{p}}$ China Meteorological and Administration, \#46 Baishiqiao Rd., Haidian, Beijing 100081, China

${ }^{\mathrm{q}}$ Chinese Academy of Meteorological Science, Institute of Atmospheric Chemistry, No. 46 Baishiqiao Rd., Beijing 100081, China ${ }^{\mathrm{r}}$ Malaysian Metrological Service, Jabatan Perkhidmatan Kajicuaca Malaysia, Jalan Sultan, 46667 Petaling Jaya, Selangor, Malaysia ${ }^{\mathrm{s}}$ BANDAN, Department of Meteorology and Geophysics, Jakarta, Indonesia

${ }^{\mathrm{t}}$ Meteorological \& Geophysical Agency, P.O. Box 3540, JL Angkasa I No. 2, Jarkata 10720, Indonesia

"PAGADA, Department of Science and Technology, 1424 Quezon Avenue, Quezon City 1104, Philippines

${ }^{v}$ Kenya Meteorological Department, Dagoretti Corner, Ngong Rd., P.O. Box 30259, Nairobi, Kenya

${ }^{\mathrm{w}}$ Deparment de la Recherche, Office National de la Meteorologie, ONM B. P. 153, Dar el Beida, Algiers, Algeria

${ }^{x}$ J.P. Lacaux, OMP/Laboratories de Aerologie, 14 Avenue Edouard Belin, Toulouse 31400, France

${ }^{y}$ HYDRECO, Laboratoire Environnement de Petit Saut, BP823, Kourou Cedex 97388, French Guiana

${ }^{\mathrm{z}}$ Ushuaia GAW Station, P.O. Box 187, Ushuaia 9410, Argentina

${ }^{\text {aa }}$ Department of Climatology, Casilla 717, Santiago, Chile

${ }^{\mathrm{ab}}$ Eixo Monumental, Via S-1, Cruseir, CEP. 70610-400 Brasilia, DF, Brazil

\footnotetext{
*Corresponding author.

E-mail addresses: gcarmich@engineering.uiowa.edu (G.R. Carmichael).
} 


\footnotetext{
${ }^{a c}$ Chemistry Istitute Departmento de Quimica Analitica, Universidade Federal da Bahia Salvador, Bahia 40210-340, Brazil

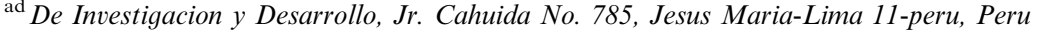

${ }^{\text {ae }}$ Turkish State Meteorological Service, Kalaba-Ankara 06120, Turkey
}

Received 20 July 2002; accepted 18 October 2002

\begin{abstract}
Measurements of gaseous $\mathrm{SO}_{2}, \mathrm{NH}_{3}$, and $\mathrm{O}_{3}$ using IVL passive sampler technology were obtained during a pilot measurement program initiated as a key component of the newly established WMO/GAW Urban Research Meteorology and Environment (GURME) project. Monthly measurements were obtained at 50 stations in Asia, Africa, South America, and Europe. The median $\mathrm{SO}_{2}$ concentrations vary from a high of $13 \mathrm{ppb}$ at Linan, China, to $<0.03 \mathrm{ppb}$ at four stations. At 30 of 50 regional stations, the observed median concentrations are $<1 \mathrm{ppb}$. Median ammonia concentrations range from $20 \mathrm{ppb}$ at Dhangadi, India, to $<1 \mathrm{ppb}$ at nine stations. At 27 of regional stations, the ambient ammonia levels exceed $1 \mathrm{ppb}$. The median ozone concentrations vary from a maximum of $45 \mathrm{ppb}$ at Waliguan Mountain, China, to $8 \mathrm{ppb}$ in Petit Saut, French Guiana. In general, the highest ozone values are found in the midlatitudes, with the Northern hemisphere mid-latitude values exceeding the Southern hemisphere mid-latitude levels, and the lowest values are typically found in the tropical regions.
\end{abstract}

(C) 2003 Elsevier Science Ltd. All rights reserved.

Keywords: Diffusive samplers; Sulfur dioxide; Ammonia; Ozone; Asia; Africa

\section{Introduction}

Measurement programs play a critical role in air pollution and atmospheric chemistry studies. Pressures of costs and changing priorities often make it difficult to maintain and expand long-term measurement programs. In some cases, environmental planning activities are severely hampered by the lack of information on the ambient levels of pollutants. Such issues are presently being faced by the World Meteorological Organization's Global Atmospheric Watch (GAW) program. GAW is a coordinated network of observing stations and related facilities whose purpose and long-term goals are to provide data, scientific assessments, and other information on changes of the chemical composition and related physical characteristics of the background atmosphere from all parts of the world. This information is needed to improve our understanding of the behavior of the atmosphere and its interactions with oceans and the biosphere and to better anticipate the future states of the earth-atmosphere system. One challenge facing the GAW program is the need to expand its activities to include measurements in each principal climatic zone and each biome, and to continue to add important species to the list of observed parameters.

Passive samplers present a means of addressing many measurement issues in air pollution and atmospheric chemistry, in that they provide a cost-effective way to monitor specific species at urban, regional, and global scales, and offer broad-capacity building opportunities. There are a variety of uses for passive samplers in atmospheric chemistry studies. They can be used: (a) to increase the spatial resolution of measurements; (b) to add species coverage to existing measurement sites; (c) to add gas-phase measurement to precipitation measurement sites; (d) in screening studies to evaluate monitoring site locations; and (e) to aid measurement programs by providing a means to increase data completion (e.g., to help keep time series complete during active instrument downtimes).

To demonstrate the expanded use of passive samplers in air quality studies, a pilot measurement program was initiated as a key component of the newly established WMO/GAW Urban Research Meteorology and Environment (GURME) project. This passive sampler project was done in collaboration and as a component of the IGAC-DEBITS program. This pilot activity combined components of three separate studies:

(1) a pilot study funded by NOAA-US Weather Service, to use passive samplers at selected WMO/ GAW stations;

(2) a continuation of the use of passive samplers as part of the RAINS-Asia Phase-II funded by the Japan Trust Fund at The World Bank; and

(3) a pilot study demonstrating the use of passive sampler at both regional and urban scales, funded by the Swedish Consultancy Fund at the World Bank.

The pilot network consisted of stations from previous studies in Asia and from existing GAW stations, along with newly established sites; in total, 50 stations in 12 Asian countries (China, India, Indonesia, Japan, Korea, Malaysia, Nepal, Philippines, Singapore, Thailand, 
Laos, and Vietnam), seven African countries (Algeria, Cameroon, Ivory Coast, Niger, Morocco, Kenya, and South Africa), five South American countries (Argentina, Brazil, Chile, Peru, and French Guyana) and a European country (Turkey). At these sites, sulfur dioxide $\left(\mathrm{SO}_{2}\right)$, ammonia $\left(\mathrm{NH}_{3}\right)$, and ozone $\left(\mathrm{O}_{3}\right)$ were monitored monthly at the rural sites and with short sampling periods at the urban sites. At the urban sites, weekly samples of $\mathrm{NO}, \mathrm{NO}_{2}, \mathrm{HCOOH}, \mathrm{CH}_{3} \mathrm{COOH}$, benzene, ethyl benzene, toluene, and xylenes were also obtained.

The project aims were: (1) to repeat a previous network for sulfur dioxide $\left(\mathrm{SO}_{2}\right)$ in Asia; and (2) to extend the capacity to monitor more pollutants in rural as well as urban air. The network provides a valuable data set that can be used for a variety of purposes including model evaluation and inter-comparison with other methods. In this paper, details and results from the regional network are presented and discussed. The urban results will be the subject of a separate paper.

\section{Passive samplers}

The samplers used here are passive; but since there are several types of passive samplers, the word diffusive sampler is more specific for these samplers and is more commonly used today. This project has, however, been titled "The Passive Sampler Project". A diffusive sampler has been defined by the European Committee for Standardization as: "A device that is capable of taking samples of gases or vapors from the atmosphere at a rate controlled by a physical process such as gaseous diffusion through a static air layer or a porous material and/or permeation through a membrane, but which does not involve active movement of air through the device". The gas molecules are transported by molecular diffusion, which is a function of air temperature and pressure. A net flux into the sampler is accomplished by placing an efficient sorbent for the target gas behind the barrier. The driving force is the difference between the ambient concentration and the concentration at the sorbent, which should be negligible, compared to the ambient concentration. The average net flux of pollutant through the sampler is obtained from analysis of the sorbent. The resistance of the barrier, as well as the timeweighted average ambient concentration, can be calculated using Fick's first law of diffusion. The solution to this equation has been published in almost all articles dealing with diffusive sampling. In order to solve it, several prerequisites must be fulfilled. These have not earlier been discussed in connection with the solution of Fick's first law. This is likely the main reason behind the poor quality of some diffusive samplers.

The following prerequisites have to be fulfilled to solve Fick's equation. At steady state, the flux (which is obtained from analysis of the sorbent) shall be constant through the sampler implying that the gas is not interacting with the wall or being transformed to another pollutant on its way to the sorbent. This is achieved by choosing an inert wall material and minimizing the residence time by using a short transport distance. The sorption must be quantitative and without interferences. The formed product must be stable. The sorption reaction must not be too slow. The sampler gives a correct average concentration even when the ambient concentration fluctuates and the flux and concentration gradient inside the sampler are not constant. This can be shown from Fick's second law of diffusion and has earlier been treated incorrectly in the literature. Other transport mechanisms than molecular diffusion or permeation must be negligible. Turbulent diffusion, convection, and rotation of the sampler can cause an active movement of air inside the sampler. This can be avoided by using a membrane at the inlet, shadowing the sampler and during personal monitoring, facing the inlet downwards. Several articles have been written on different parts of the theory behind diffusive sampling, but some parts have been missing. A summary of the published parts and an addition of some missing parts for diffusive samplers using irreversible sorption and a constant cross-sectional area (tube or badge type) has recently been published (Ferm, 2001a).

A large number of different diffusive samplers for use in outdoor air have been developed since Palmes and Gunnison published a description of the first sampler (Palmes and Gunnison, 1973). Several of them are today commercially available. The quality of the results from these samplers has varied widely and the technology has therefore occasionally suffered from a bad reputation. This study utilized diffusive samplers developed at the IVL. At IVL, diffusive samplers for several gases have been developed and described in the literature (Ferm and Rodhe, 1997). They are fully based on these theories implying that the ambient concentration is calculated from the theoretical uptake rate and not from an empirical one. This is to ensure that there are no biases that we are not aware of.

The quality does, however, not only depend on the sampler, but also on the analysis, the choice of sampling points, design of network and the evaluation of results. Stevenson et al. (2001) investigated in a laboratory intercomparison the variation between different laboratories for analyses of doped Palmes tubes. They found that the coefficient of variation (a statistical measure of precision based on the difference between duplicate samples) was for most laboratories within $\pm 25 \%$, which is acceptable for indicative monitoring.

In order to use diffusive measurements instead of volumetric or instrumental analyses, an analytical precision around $\pm 5 \%$ is needed. At IVL, the analytical procedures for the diffusive samplers therefore have 
been accredited. This implies that certified standards are used and statistical analyses of accuracy and precision of duplicates and reference samples are maintained by the use of control charts every time a batch of samples is

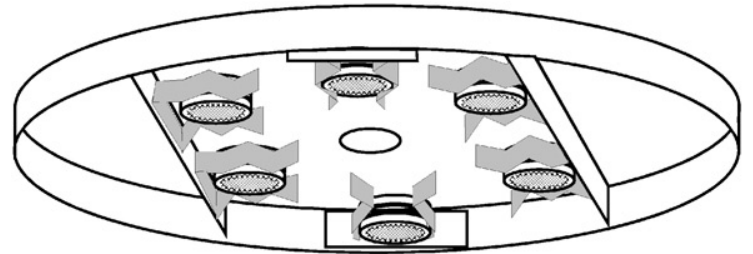

Fig. 1. Six diffusive samplers mounted under a metal disc. analyzed. An analysis of a diffusive sampler has to be performed by personnel accredited for the analyses in question. The laboratory at IVL has to participate in intercomparisons to keep the accreditation. Furthermore, the IVL is participating in the standardization work for testing diffusive samplers within the CEN (European Committee for Standardization).

The IVL samplers are of badge type, $10 \mathrm{~mm}$ long and $20 \mathrm{~mm}$ internal diameter. A membrane is mounted at the inlet to prevent them from wind-induced turbulent diffusion. The membrane is protected from mechanical damage by a stainless steel mesh. The $\mathrm{SO}_{2}$ and $\mathrm{NO}_{2}$ samplers have been compared to active sampling within a routine network (Ferm and Svanberg, 1998).
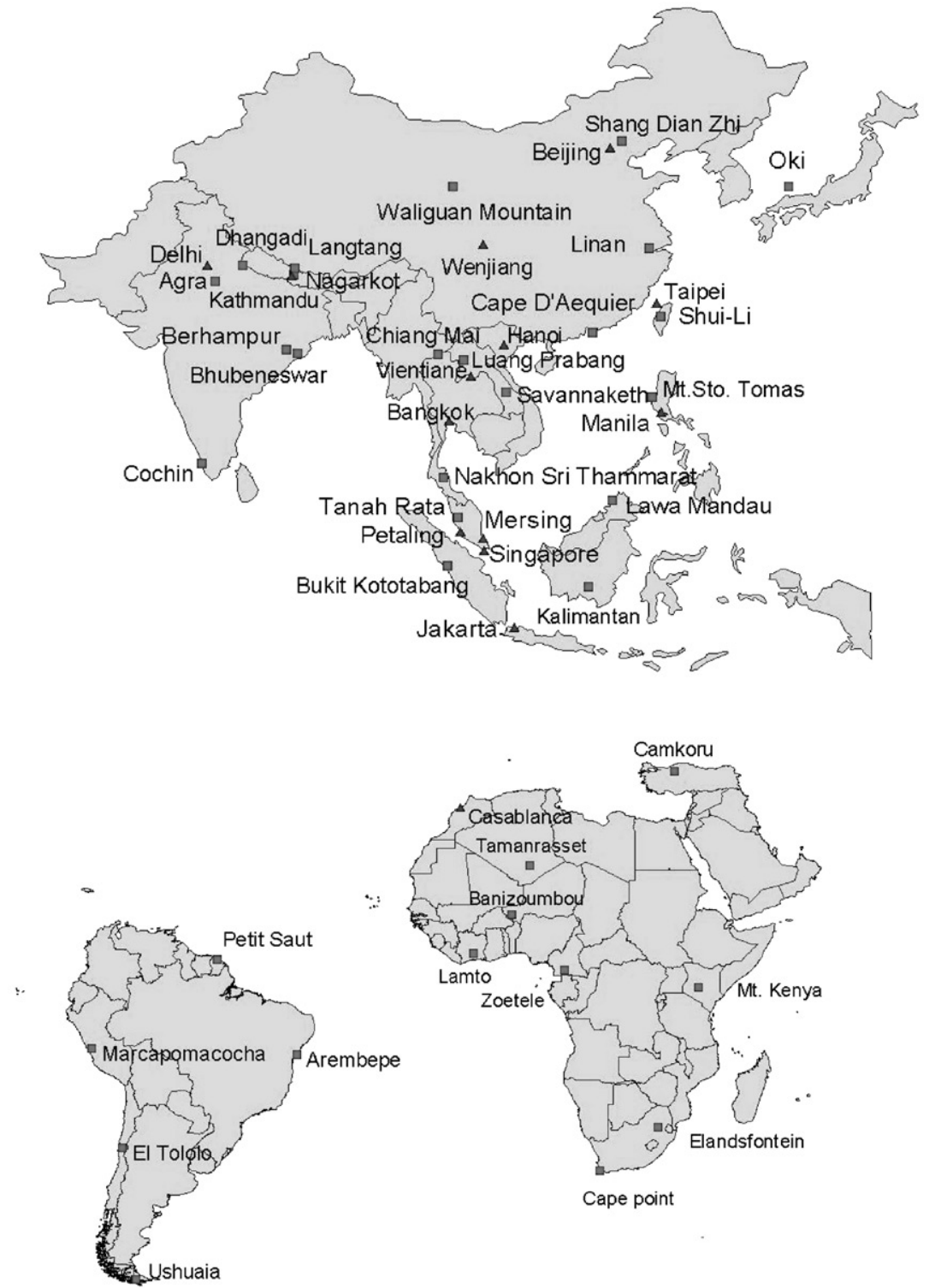

Fig. 2. Location of the measurement sites used in this study (squares and triangles represent regional and urban sites, respectively). 
Table 1

Station information

\begin{tabular}{|c|c|c|c|c|c|}
\hline \multirow[t]{2}{*}{ Country } & \multirow[t]{2}{*}{ Station } & \multicolumn{3}{|l|}{ Location } & \multirow[t]{2}{*}{ Level } \\
\hline & & Latitude & Longitude & Elevation (m) & \\
\hline \multirow[t]{6}{*}{ China } & Waliguan mountain & $36^{\circ} 17^{\prime} \mathrm{N}$ & $100^{\circ} 54^{\prime} \mathrm{E}$ & 3810 & I \\
\hline & Linan & $30^{\circ} 18^{\prime} \mathrm{N}$ & $119^{\circ} 44^{\prime} \mathrm{E}$ & 132 & I \\
\hline & Shang dian Zhi & $40^{\circ} 39^{\prime} \mathrm{N}$ & $117^{\circ} 07^{\prime} \mathrm{E}$ & 260 & I \\
\hline & Cape D'Aequier & $22^{\circ} 12^{\prime} \mathrm{N}$ & $114^{\circ} 15^{\prime} \mathrm{E}$ & $\sim 1$ & I \\
\hline & Beijing & $\sim 40^{\circ} 2^{\prime} \mathrm{N}$ & $\sim 116^{\circ} 25^{\prime} \mathrm{E}$ & $\sim 137$ & II \\
\hline & Wenjiang & $30^{\circ} 42^{\prime} \mathrm{N}$ & $103^{\circ} 50^{\prime} \mathrm{E}$ & $\sim 488$ & II \\
\hline \multirow[t]{2}{*}{ Taiwan } & Taipei & $25^{\circ} 2.55^{\prime} \mathrm{N}$ & $120^{\circ} 30.82^{\prime} \mathrm{E}$ & $\sim 0$ & II \\
\hline & Shui-Li & $23^{\circ} 49.1^{\prime} \mathrm{N}$ & $120^{\circ} 50.86^{\prime} \mathrm{E}$ & 330 & $\mathrm{I}$ \\
\hline Japan & Oki & $36^{\circ} 17^{\prime} \mathrm{N}$ & $133^{\circ} 11^{\prime} \mathrm{E}$ & 90 & I \\
\hline \multirow[t]{4}{*}{ Malaysia } & Tanah Rata & $04^{\circ} 28^{\prime} \mathrm{N}$ & $101^{\circ} 22^{\prime} \mathrm{E}$ & 1471 & I \\
\hline & Petaling Jaya & $03^{\circ} 06^{\prime} \mathrm{N}$ & $101^{\circ} 39^{\prime} \mathrm{E}$ & 45 & II \\
\hline & Mersing & $02^{\circ} 27^{\prime} \mathrm{N}$ & $103^{\circ} 50^{\prime} \mathrm{E}$ & 44 & II \\
\hline & Lawa Mandau & $06^{\circ} 02^{\prime} \mathrm{N}$ & $116^{\circ} 12^{\prime} \mathrm{E}$ & 830 & $\mathrm{I}$ \\
\hline \multirow[t]{3}{*}{ Indonesia } & Bukit Kototabang & $0^{\circ} 12^{\prime} \mathrm{S}$ & $100^{\circ} 19^{\prime} \mathrm{E}$ & 865 & I \\
\hline & Jakarta & $6^{\circ} 10^{\prime} \mathrm{S}$ & $106^{\circ} 48^{\prime} \mathrm{E}$ & $\sim 61$ & II \\
\hline & Kalimantan & $2^{\circ} 16^{\prime} \mathrm{S}$ & $113^{\circ} 56^{\prime} \mathrm{E}$ & $\sim 0$ & I \\
\hline Vietnam & Hanoi & $21^{\circ} 01^{\prime} \mathrm{N}$ & $105^{\circ} 51^{\prime} \mathrm{E}$ & $\sim 122$ & II \\
\hline \multirow[t]{3}{*}{ Thailand } & Bangkok & $13^{\circ} 45^{\prime} \mathrm{N}$ & $100^{\circ} 32^{\prime} \mathrm{E}$ & 1 & II \\
\hline & Chiang Mai & $20^{\circ} 5^{\prime} \mathrm{N}$ & $99^{\circ} 23^{\prime} \mathrm{E}$ & $\sim 807$ & $\mathrm{I}$ \\
\hline & Nakhon Sri Thammarat & $\sim 8^{\circ} 15^{\prime} \mathrm{N}$ & $\sim 100^{\circ} \mathrm{E}$ & $\sim 10$ & I \\
\hline \multirow[t]{3}{*}{ Laos } & Luang Prabang & $19^{\circ} 36^{\prime} \mathrm{N}$ & $101^{\circ} 54^{\prime} \mathrm{E}$ & 640 & I \\
\hline & Vientiane & $18^{\circ} \mathrm{N}$ & $102^{\circ} 36^{\prime} 55^{\prime \prime} \mathrm{E}$ & 200 & II \\
\hline & Savannaketh & $16^{\circ} 30^{\prime} \mathrm{N}$ & $106^{\circ} \mathrm{E}$ & 200 & I \\
\hline \multirow[t]{2}{*}{ Philippines } & Mt. Sto. Tomas & $16^{\circ} \mathrm{N}$ & $120^{\circ} \mathrm{E}$ & 2200 & I \\
\hline & Manila & $14^{\circ} 35^{\prime} \mathrm{N}$ & $121^{\circ} \mathrm{E}$ & $\sim 15$ & II \\
\hline Singapore & Singapore & $1^{\circ} 16^{\prime} \mathrm{N}$ & $103^{\circ} 51^{\prime} \mathrm{E}$ & $\sim 0$ & II \\
\hline \multirow[t]{4}{*}{ Nepal } & Kathmandu & $27^{\circ} 42^{\prime} \mathrm{N}$ & $85^{\circ} 22^{\prime} \mathrm{E}$ & $\sim 1524$ & II \\
\hline & Dhangadi & $28^{\circ} 41^{\prime} \mathrm{N}$ & $80^{\circ} 36^{\prime} \mathrm{E}$ & $\sim 166$ & I \\
\hline & Nagarkot & $27^{\circ} 45^{\prime} \mathrm{N}$ & $85^{\circ} 34^{\prime} \mathrm{E}$ & $\sim 948$ & I \\
\hline & Langtang & $28^{\circ} 43^{\prime} \mathrm{N}$ & $85^{\circ} 37^{\prime} \mathrm{E}$ & $\sim 4676$ & I \\
\hline \multirow[t]{5}{*}{ India } & Delhi & $28^{\circ} 40^{\prime} \mathrm{N}$ & $77^{\circ} 13^{\prime} \mathrm{E}$ & $\sim 213$ & II \\
\hline & Berhampur & $20^{\circ} 36^{\prime} \mathrm{N}$ & $84^{\circ} 48^{\prime} \mathrm{E}$ & $\sim 316$ & I \\
\hline & Cochin & $9^{\circ} 35^{\prime} \mathrm{N}$ & $76^{\circ} 44^{\prime} \mathrm{E}$ & $\sim 91$ & $\mathrm{I}$ \\
\hline & Agra & $27^{\circ} 11^{\prime} \mathrm{N}$ & $78^{\circ} 01^{\prime} \mathrm{E}$ & $\sim 175$ & I \\
\hline & Bhubeneswar & $20^{\circ} 15^{\prime} \mathrm{N}$ & $85^{\circ} 52^{\prime} \mathrm{E}$ & $\sim 24$ & I \\
\hline Kenya & Mt. Kenya & $0^{\circ} \mathrm{S}$ & $37^{\circ} \mathrm{E}$ & 3780 & I \\
\hline \multirow[t]{2}{*}{ South Africa } & Elandsfontein & $26^{\circ} 15^{\prime} \mathrm{S}$ & $29^{\circ} 25^{\prime} \mathrm{E}$ & 1500 & I \\
\hline & Cape point & $34^{\circ} 21^{\prime} \mathrm{S}$ & $18^{\circ} 29^{\prime} \mathrm{E}$ & 230 & I \\
\hline Algeria & Tamanrasset & $22^{\circ} 47^{\prime} \mathrm{N}$ & $5^{\circ} 31^{\prime} \mathrm{E}$ & 1377 & I \\
\hline Niger & Banizoumbou & $13^{\circ} 32^{\prime} \mathrm{N}$ & $2^{\circ} 04^{\prime} \mathrm{E}$ & 220 & I \\
\hline
\end{tabular}


Table 1 (continued)

\begin{tabular}{|c|c|c|c|c|c|}
\hline \multirow[t]{2}{*}{ Country } & \multirow[t]{2}{*}{ Station } & \multicolumn{3}{|l|}{ Location } & \multirow[t]{2}{*}{ Level } \\
\hline & & Latitude & Longitude & Elevation (m) & \\
\hline Ivory Coast & Lamto & $6^{\circ} 13^{\prime} \mathrm{N}$ & $5^{\circ} 01^{\prime} \mathrm{W}$ & 136 & I \\
\hline Cameroon & Zoetele & $3^{\circ} 15^{\prime} \mathrm{N}$ & $11^{\circ} 53^{\prime} \mathrm{E}$ & 720 & I \\
\hline French Guiana & Petit Saut & $5^{\circ} 03^{\prime} \mathrm{N}$ & $53^{\circ} 03^{\prime} \mathrm{W}$ & 50 & I \\
\hline \multirow[t]{2}{*}{ Argentina } & Isla Redonda & $54^{\circ} 51^{\prime} \mathrm{S}$ & $68^{\circ} 29^{\prime} \mathrm{W}$ & 3459 & I \\
\hline & Ushuaia & $54^{\circ} 49^{\prime} \mathrm{S}$ & $68^{\circ} 19^{\prime} \mathrm{W}$ & 10 & I \\
\hline Chile & El Tololo & $30^{\circ} 10^{\prime} \mathrm{S}$ & $70^{\circ} 48^{\prime} \mathrm{W}$ & $\sim 2172$ & I \\
\hline Brazil & Arembepe & $12^{\circ} 46^{\prime} \mathrm{S}$ & $38^{\circ} 10^{\prime} \mathrm{W}$ & 0 & I \\
\hline Peru & Marcapomacocha & $11^{\circ} 33.7^{\prime} \mathrm{S}$ & $76^{\circ} 27.3^{\prime} \mathrm{W}$ & 4467 & I \\
\hline Turkey & Camkoru & $32^{\circ} 29^{\prime} \mathrm{N}$ & $40^{\circ} 28^{\prime} \mathrm{E}$ & 1350 & I \\
\hline Morocco & Casablanca & $\sim 33^{\circ} 39^{\prime} \mathrm{N}$ & $\sim 7^{\circ} 35^{\prime} \mathrm{W}$ & $\sim 137$ & II \\
\hline
\end{tabular}

Level I means "Regional Station” and Level II means "Urban/suburban Station”.

Additional information of the use of IVL-type samplers and their comparison with active sampling results can be found in Ayers et al. $(1998,2000,2002)$ and Gillett et al. (2000). The $\mathrm{NH}_{3}$ sampler was tested in an intercomparison (Kirchner et al., 1999). The $\mathrm{O}_{3}$ sampler was compared with UV-instrument (Sjöberg et al., 2001). The ozone sampler has also been validated for use in workplace atmospheres (Ferm, 2001b). All the samplers are also undergoing intercomparisons within CEN.

\subsection{Sampling}

The samplers were prepared at IVL and mailed together with instructions to the contact persons in each country. The samplers were mounted under a metal disc ca $3 \mathrm{~m}$ above the ground in order to protect them for rain and direct sunshine, see Fig. 1. After 1-month exposure, the samplers were returned to IVL for analysis. Some were not exposed and returned as field blanks. Duplicates were always used.

The detection limit was estimated from a sampled amount corresponding to three times the standard deviation of the average field blanks using the actual exposure time. For exactly 1-month sampling, this corresponded to $0.03\left(\mathrm{SO}_{2}\right), 1\left(\mathrm{NH}_{3}\right)$ and $0.6\left(\mathrm{O}_{3}\right) \mathrm{ppb}$. For the $\mathrm{SO}_{2}$ measurements, $13 \%$ were below the detection limit and for $\mathrm{NH}_{3} 32 \%$ were below the detection limit. The upper limit was exceeded for $5 \%$ of the $\mathrm{NH}_{3}$ measurements (only in India and Nepal). The upper limit, based on a sampled amount corresponding to half the stoichiometric amount of sorbent and exactly 1-month sampling, was $32 \mathrm{ppb}$. In several of these samples, the ammonium amount found was equal to the stoichiometric amount of sorbent. In these cases, the upper limit was estimated from the sampled amount and the actual exposure time.

The coefficients of variation $(\mathrm{COV}$, a measure of the precision, here it is defined as the median relative standard deviation, assuming a normal distribution of the deviation between parallel samples) for all duplicates within the detection limits were: $12 \%, 20 \%$, and $3.6 \%$ for $\mathrm{SO}_{2}, \mathrm{NH}_{3}$, and $\mathrm{O}_{3}$, respectively. The detection limits divided by the median concentrations were $13 \%, 23 \%$, and $3 \%$, respectively. The COV (calculated in the same way) for $\mathrm{SO}_{2}$ in an earlier test was $10 \%$ (Ferm and Rodhe, 1997). The COV for $\mathrm{NH}_{3}$ was in the earlier test $25 \%$ when the membrane was not exchanged with a solid lid after exposure. When the membrane was exchanged, the COV was improved to $21 \%$. In this study, membranes were changed incorrectly on several occasions. The measured $\mathrm{NH}_{3}$ concentrations can therefore be somewhat over-estimated due to evaporation of $\mathrm{NH}_{3}$ from deposited particulate matter. The $\mathrm{COV}$ for $\mathrm{O}_{3}$ is similar to that earlier observed in Sweden. The accuracy could not be estimated since we did not receive data from parallel measurements using other techniques.

Diffusive sampling is a very foolproof technique. There are very few things that can affect the results if the sampling protocol is not followed. The samplers are color marked. Sometimes they were sent back in the wrong storage container. This was noted during the 
Table 2

Median concentrations in $\mathrm{ppb}$, and number of valid samplers at the sampling sites

\begin{tabular}{|c|c|c|c|c|c|c|}
\hline Station & $\begin{array}{l}\text { Median } \\
\mathrm{SO}_{2} \\
(\mathrm{ppb})\end{array}$ & $\begin{array}{l}\text { Median } \\
\mathrm{NH}_{3} \\
(\mathrm{ppb})\end{array}$ & $\begin{array}{l}\text { Median } \\
\mathrm{O}_{3} \\
(\mathrm{ppb})\end{array}$ & $\begin{array}{l}\text { Number } \\
\text { of months } \\
\text { with } \\
\text { returned } \\
\text { samplers }^{\text {a }}\end{array}$ & $\begin{array}{l}\text { Number of } \\
\mathrm{SO}_{2} \text { samples } \\
\text { within } \\
\text { detection limit }^{\mathrm{b}}\end{array}$ & $\begin{array}{l}\text { Number of } \\
\mathrm{NH}_{3} \text { samples } \\
\text { within } \\
\text { detection } \\
\text { limit }^{\mathrm{b}}\end{array}$ \\
\hline Waliguan mountain & 0.26 & 4 & 44.9 & 6 & 6 & 6 \\
\hline Linan & 13.06 & 5 & 38.3 & 9 & 9 & 9 \\
\hline Shang dian Zhi & 3.85 & 3 & 38.0 & 9 & 9 & 7 \\
\hline Cape D'Aequier & 0.64 & 1 & 34.9 & 11 & 11 & 5 \\
\hline Shui-Li & 0.78 & 7 & 25.0 & 12 & 12 & 12 \\
\hline Oki & 0.32 & $<1$ & 40.4 & 12 & 12 & 0 \\
\hline Tanah Rata & 0.06 & $<1$ & 16.0 & 12 & 11 & 3 \\
\hline Lawa Mandau & 0.16 & $<1$ & 17.0 & 11 & 11 & 3 \\
\hline Bukit Kototabang & 0.05 & 3 & 10.7 & 7 & 6 & 6 \\
\hline Kalimantan & 0.11 & 6 & 10.2 & 7 & 7 & 7 \\
\hline Chiang Mai & 0.07 & 2 & 13.7 & 11 & 11 & 11 \\
\hline Nakhon Sri Thammarat & 0.14 & 1 & 9.2 & 12 & 12 & 8 \\
\hline Luang Prabang & 0.03 & 3 & 11.2 & 11 & 5 & 11 \\
\hline Savannaketh & 0.12 & 1 & 15.3 & 9 & 7 & 7 \\
\hline Mt. Sto. Tomas & 0.11 & 2 & 26.2 & 9 & 9 & 5 \\
\hline Dhangadi & 0.21 & 22 & 15.2 & 13 & 13 & 11 \\
\hline Nagarkot & 0.18 & 2 & 33.1 & 12 & 11 & 10 \\
\hline Langtang & $<0.03$ & 1 & 32.4 & 11 & 2 & 6 \\
\hline Berhampur & 0.40 & 8 & 23.7 & 11 & 11 & 11 \\
\hline Cochin & 4.77 & 19 & 11.8 & 11 & 11 & 8 \\
\hline Agra & 1.79 & $>40$ & 30.8 & 12 & 12 & 0 \\
\hline Bhubeneswar & 0.79 & 7 & 31.4 & 22 & 22 & 22 \\
\hline Mt. Kenya & 0.03 & 1 & 30.0 & 8 & 4 & 6 \\
\hline Elandsfontein & 6.99 & 2 & 35.1 & 10 & 10 & 10 \\
\hline Cape point & 0.30 & 1 & 24.2 & 12 & 12 & 7 \\
\hline Tamanrasset & 0.08 & 4 & 33.2 & 12 & 12 & 12 \\
\hline Banizoumbou & 0.07 & 4 & 25.7 & 12 & 8 & 10 \\
\hline Lamto & 0.08 & 3 & 14.9 & 12 & 8 & 9 \\
\hline Zoetele & $<0.03$ & 2 & 7.2 & 7 & 2 & 6 \\
\hline Petit Saut & 0.14 & $<1$ & 8.4 & 12 & 12 & 0 \\
\hline Isla Redonda & $<0.03$ & $<1$ & 15.9 & 4 & 1 & 0 \\
\hline Ushuaia & $<0.03$ & $<1$ & 16.7 & 7 & 3 & 1 \\
\hline El Tololo & 0.22 & $<1$ & 30.6 & 14 & 14 & 1 \\
\hline Arembepe & 0.07 & $<1$ & 19.2 & 5 & 4 & 2 \\
\hline Marcapomacocha & 3.09 & 3 & 25.1 & 6 & 6 & 5 \\
\hline Camkoru & 0.58 & $<1$ & 35.4 & 12 & 12 & 0 \\
\hline
\end{tabular}

${ }^{\mathrm{a}}$ This is the number of months that samplers were returned for analysis. All $\mathrm{O}_{3}$ samplers were within detection limits. Numbers $<12$ indicate problems with getting samplers into and out of the country, and local problem at the sites.

${ }^{b}$ The difference in the number of samplers exposed and the number of valid samplers represents the number of samplers that have mixing ratios that are either above or below the detection limit.

unpacking. At one station, blanks and samples were mixed, which was easily discovered. The mounting of the rain shield is simple and photos of the mounted equipment have been received from most stations. We therefore believe that the accuracy is similar to that estimated within the accreditation. The average of the duplicates was used here except from a very few cases ( 5 for $\mathrm{SO}_{2}, 3$ for $\mathrm{NH}_{3}$, and 2 for $\mathrm{O}_{3}$ ) when contamination was suspected.

\subsection{Site information}

These passive samplers were sent to 50 stations throughout Asia, South America, Africa, and Turkey. At the 36 stations representing the regional sites, $\mathrm{SO}_{2}$, $\mathrm{NH}_{3}$, and $\mathrm{O}_{3}$ were sampled on a monthly basis. Most sites began measurement in September 1999 and conducted measurements for 12 months. Measurement at some sites started later and/or ran for longer periods. 


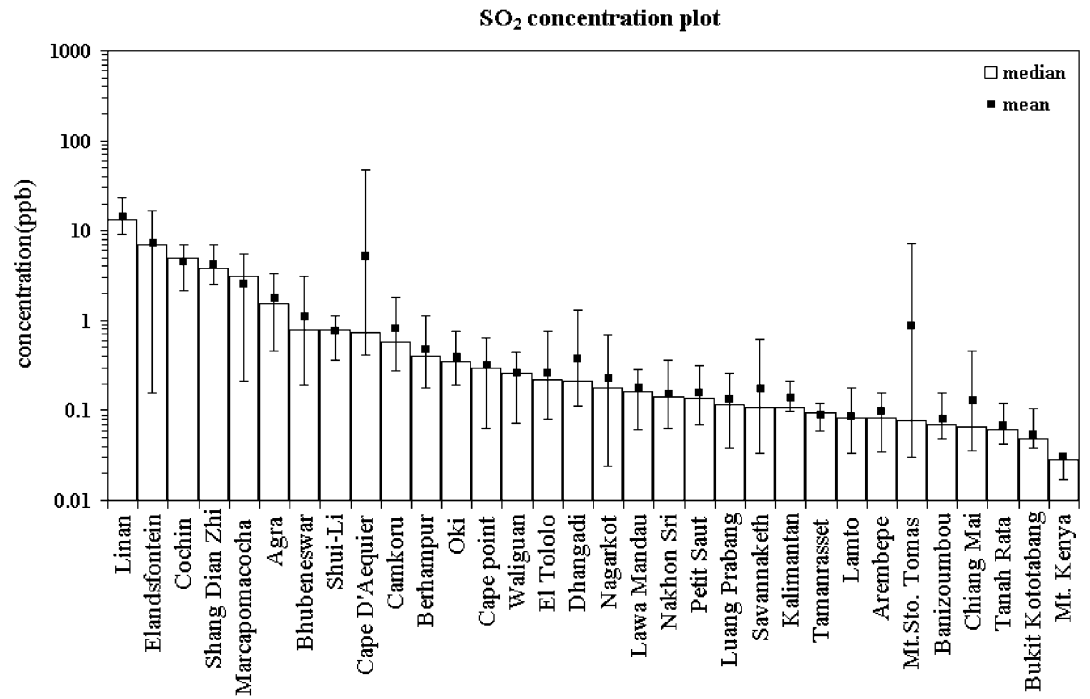

Fig. 3. Measured $\mathrm{SO}_{2}$ concentrations. The bars indicate maximum, minimum and mean values, and the solid box designates the median values.

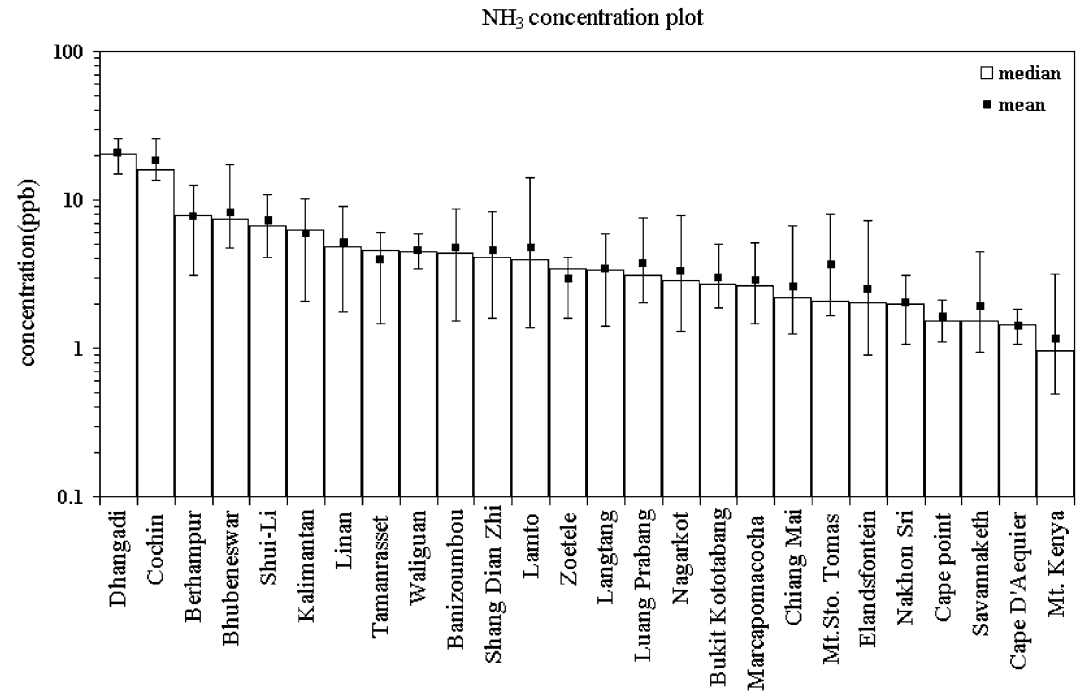

Fig. 4. Measured $\mathrm{NH}_{3}$ concentrations. The bars indicate maximum, minimum and mean values, and the solid box designates the median values.

The longest measurement period extended from September 1999 to June 2001. Maps of these sampling sites and station details are presented in Fig. 2 and Table 1 , respectively. The regional sites were chosen to be representative of rural conditions. Sites were chosen when possible to be away from local sources, including roads. Detailed site information including photographs are available on the project web site (http://www.cgrer.uiowa.edu/people/nthongbo/Passive/passmain.html).

\section{Result and discussion}

A summary of the observed values is presented in Table 2. The number of samples returned, along with the number of samples within the detection limit, is presented. The observed median concentrations of $\mathrm{SO}_{2}, \mathrm{NH}_{3}$, and $\mathrm{O}_{3}$ obtained at the regional sites are shown in Figs. 3, 4, and 6, respectively. The mean, median, and maximum and minimum monthly values 


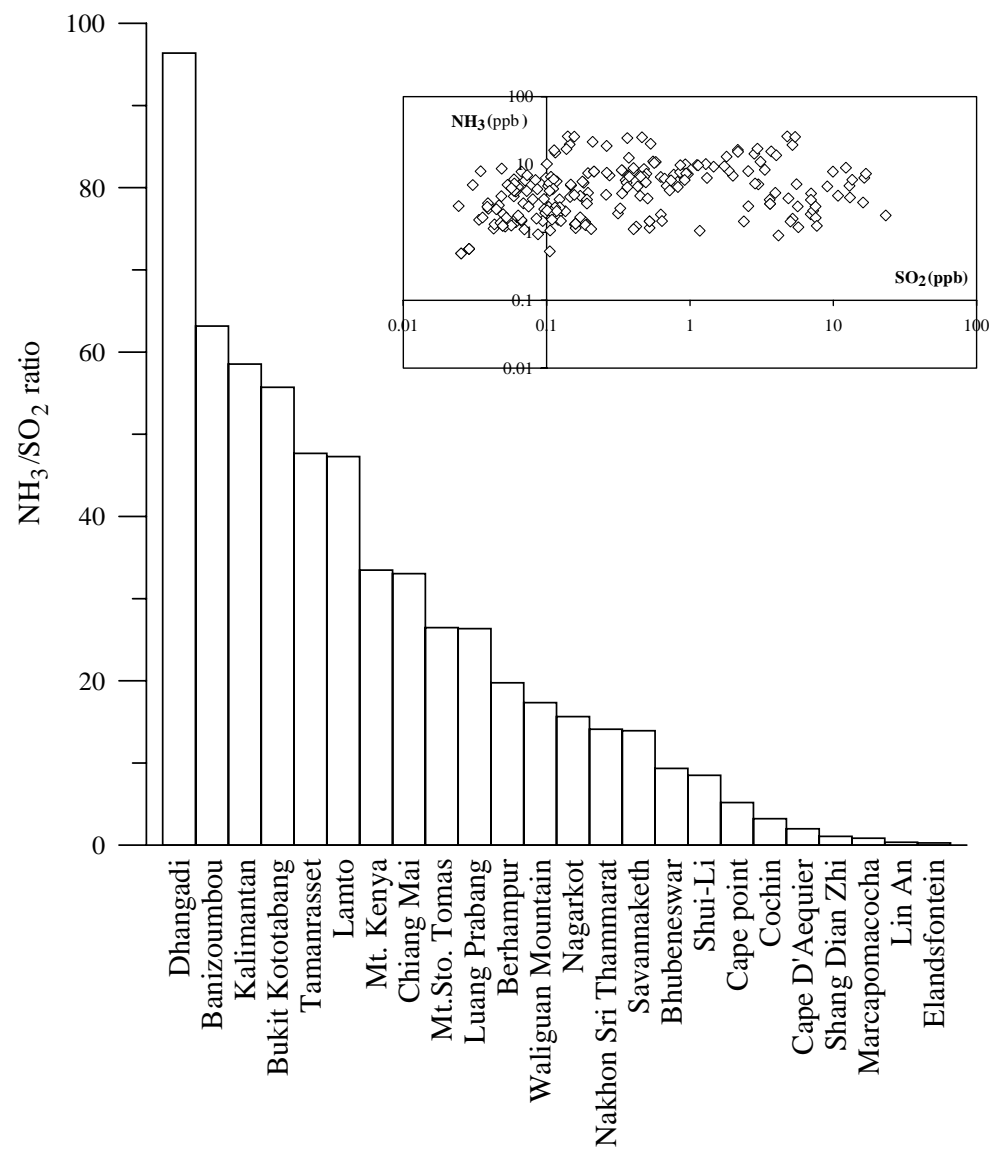

Fig. 5. Ratios of median $\mathrm{NH}_{3}$ to $\mathrm{SO}_{2}$ concentrations. Insert shows the monthly $\mathrm{NH}_{3}$ and $\mathrm{SO}_{2}$ concentrations.

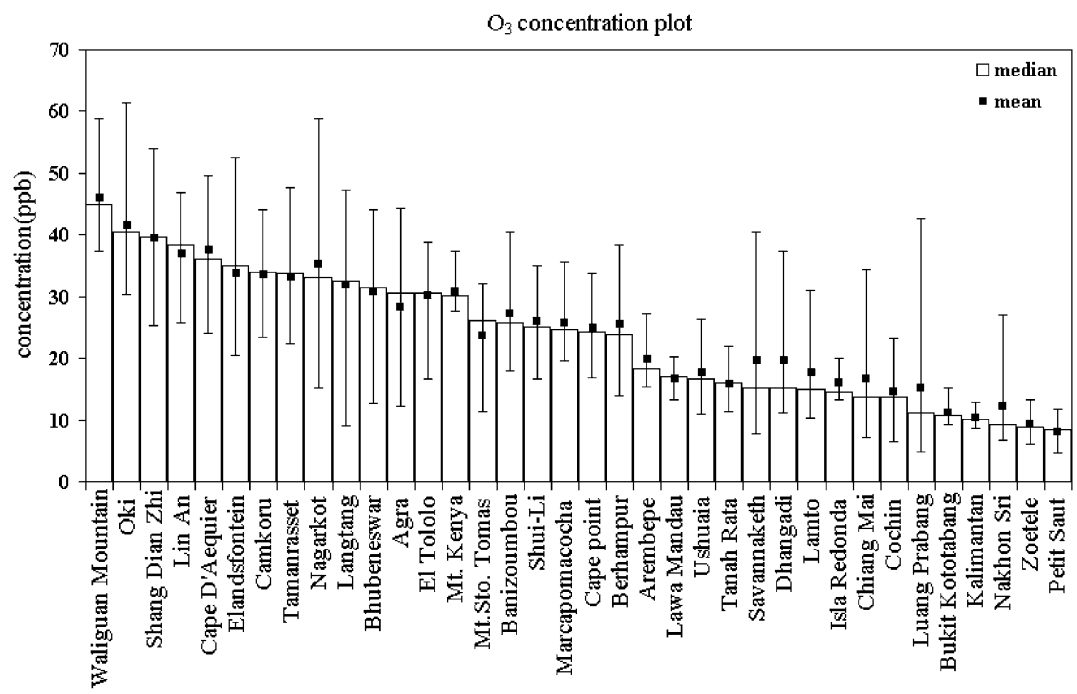

Fig. 6. Measured $\mathrm{O}_{3}$ concentrations. The bars indicate maximum, minimum and mean values, and the solid box designates the median values. 
$\mathrm{O}_{3}$ median concentration plot sorted by latitude from north to south

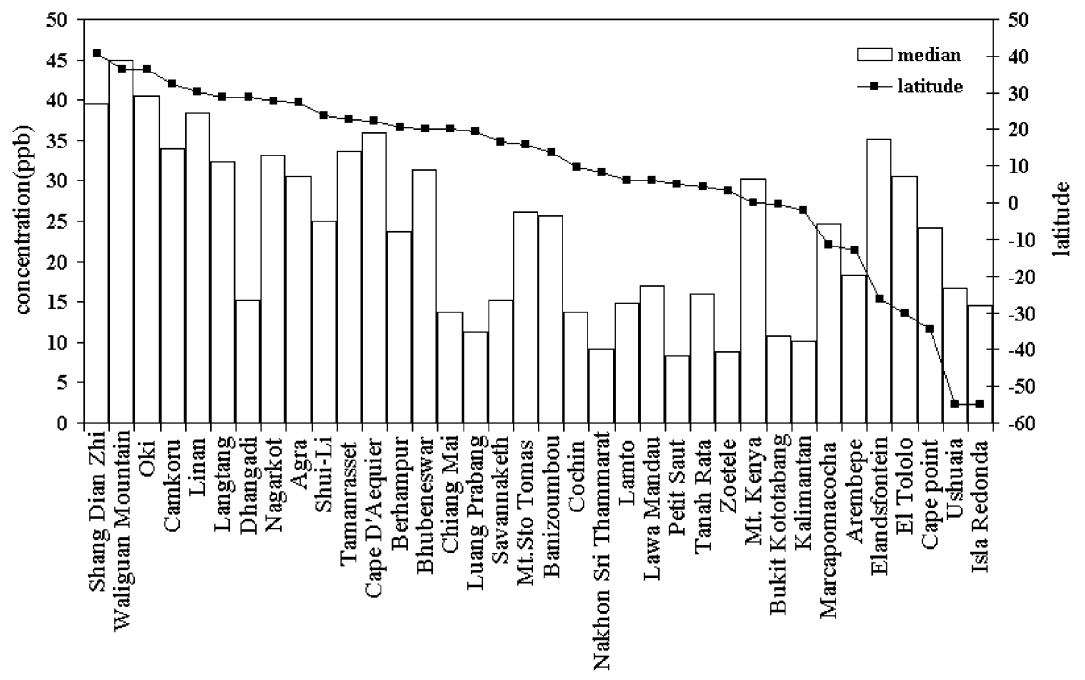

Fig. 7. Latitudinal variation in observed $\mathrm{O}_{3}$.

are shown. The range reflects the strength of the seasonal cycle and will be discussed later. The observed $\mathrm{SO}_{2}$ concentrations (Fig. 3) vary from a high of $13 \mathrm{ppb}$ at Linan, China, to $<0.03 \mathrm{ppb}$ at four stations. At 30 of 36 regional stations, the observed mean annual concentrations were $<1.0 \mathrm{ppb}$. The high concentrations of $\mathrm{SO}_{2}$ at Linan, China, Elandsfontein, S. Africa, Cochin, India, Shang Dian Zhi China, Marcapomacocha, Peru, and Agra, India, reflect major contributions from anthropogenic $\mathrm{SO}_{2}$ emissions (i.e., power plant, industrial boilers, heating, and cooking). Most stations show a consistency between the median and mean concentrations. The largest disagreements occurred at Cape D' Aequier, Hong Kong, and Mt. Sto. Tomas, Philippines. At the Hong Kong site, this was due to a rusted sampler mesh. Mt. Sto. Tomas levels of $\mathrm{SO}_{2}$ were impacted by the eruption of the Mayon volcano at the end of February 2000 (see Fig. 10).

Median ammonia concentrations shown in Fig. 4 range from $20 \mathrm{ppb}$ at Dhangadi, India, to $<1 \mathrm{ppb}$ at nine stations. At 27 sites, the ambient ammonia levels exceeded $1 \mathrm{ppb}$. The high median $\mathrm{NH}_{3}$ concentration in the Indian sub-continent, Southeast and South Asia, and Africa reflect high $\mathrm{NH}_{3}$ emissions from agricultural activities (including fertilizer use), livestock, and the use of biofuels (such as animal dung) as domestic fuel.

$\mathrm{SO}_{2}$ and ammonia play important roles in aerosol processes, and in influencing the acidity of precipitation. While $\mathrm{SO}_{2}$ has been relatively widely studied, little information is available on ambient $\mathrm{NH}_{3}$ levels for large regions of the World. The ratio of gaseous ammonia to sulfur dioxide provides insight into the relative importance of these species. The ratios of observed ammonia to sulfur dioxide are presented in Fig. 5. At 24 sites the ammonia-mixing ratios exceed those of $\mathrm{SO}_{2}$, and at 15 sites the ratio exceeds 10 .

The median ozone concentrations (Fig. 6) vary from a maximum of $45 \mathrm{ppb}$ at Waliguan Mountain, China, to $8 \mathrm{ppb}$ in Petit Saut, French Guiana. The sorted plot of ozone concentration with latitude (Fig. 7) shows that the four stations with the highest ozone levels (Oki, Japan; Waliguan Mountain, Shang Dian Zhi, and Linan, China) are in the Northern Hemisphere mid-latitudes. In general, the highest values are found in the midlatitudes of the Northern and Southern hemisphere, with the Northern hemisphere mid-latitude values exceeding the Southern hemisphere mid-latitude levels, and with the lowest values typically found in the tropical regions.

The observed $\mathrm{SO}_{2}, \mathrm{NH}_{3}$, and $\mathrm{O}_{3}$ values in Asia are plotted along with the emissions distributions in Fig. 8. In general, the observations reflect the spatial distributions of the emissions. $\mathrm{SO}_{2}$ and ammonia are primary pollutants, and both have high emissions around the major urban and industrial centers. However, ammonia emissions are more widespread, reflecting the large contribution due to agricultural activity. Ozone is a secondary pollutant formed by photochemical processes involving $\mathrm{NO}_{x}$ and reactive hydrocarbons. High ozone levels are found in regions of high $\mathrm{NO}_{x}$ and reactive hydrocarbon emissions as seen at Linan and Cape D'Aequier. But high levels are also found at Waliguan Mountain, reflecting high background levels in the midtroposphere.

Time-series of monthly values at selected sites are presented in Figs. 9 and 10. The seasonal variation in ambient levels varies from station to station and 
(a)
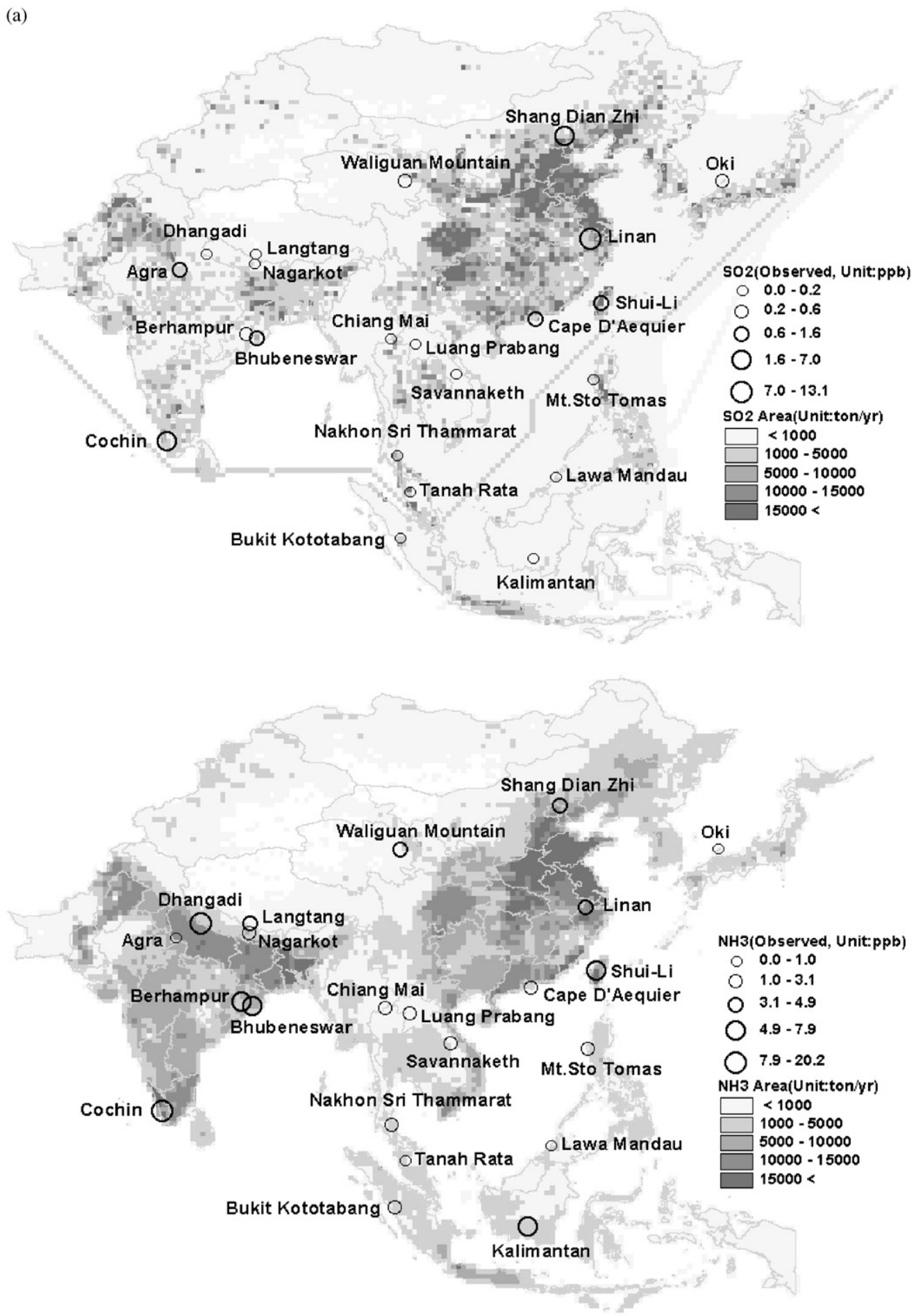

Fig. 8. (a) Observed median $\mathrm{SO}_{2}$ and $\mathrm{NH}_{3}$ in Asia plotted along with the emissions distributions of $\mathrm{SO}_{2}$ (top) and $\mathrm{NH}_{3}$ (bottom). (b) Observed median $\mathrm{O}_{3}$ values in Asia plotted along with the emissions distribution of $\mathrm{NO}_{x}$ (top) and the ratio of non-methane volatile organic carbon (NMVOC) to $\mathrm{NO}_{x}$ ratios (bottom). 
(b)

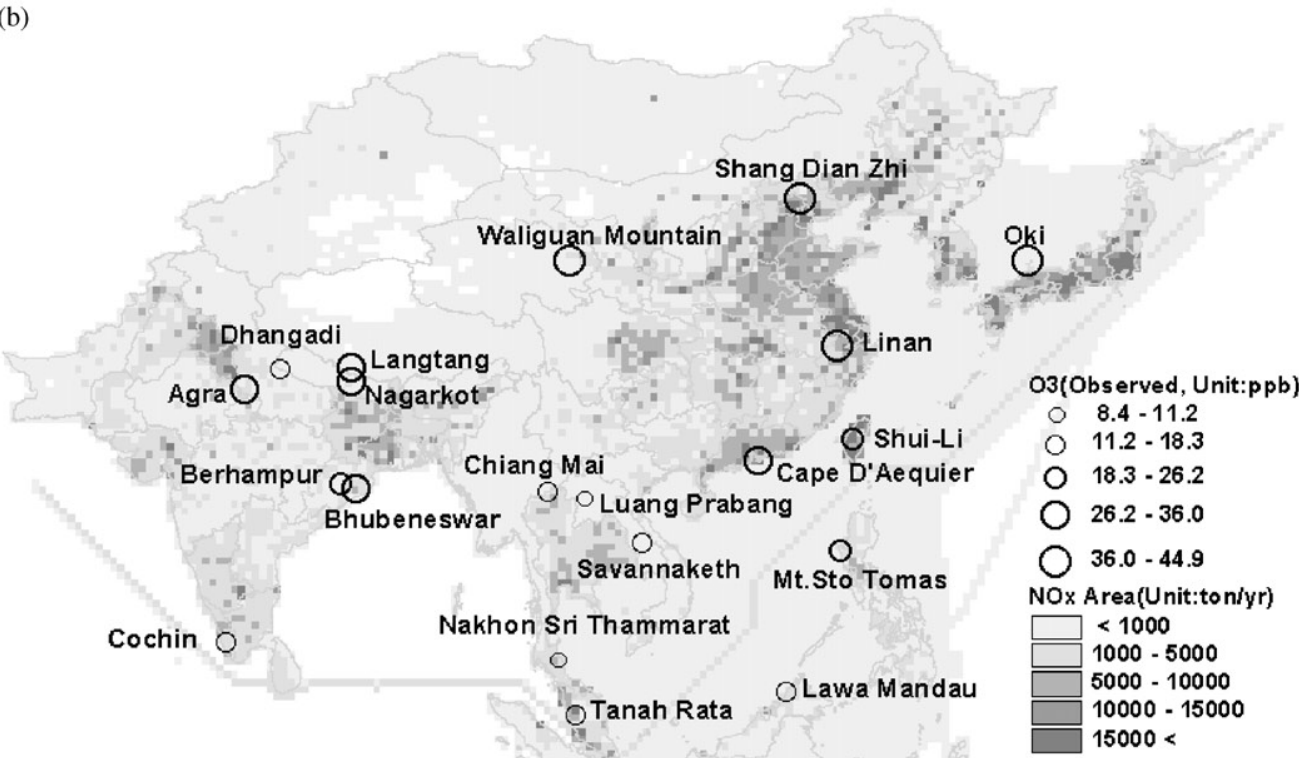

Bukit Kototabang 0

0

Kalimantan

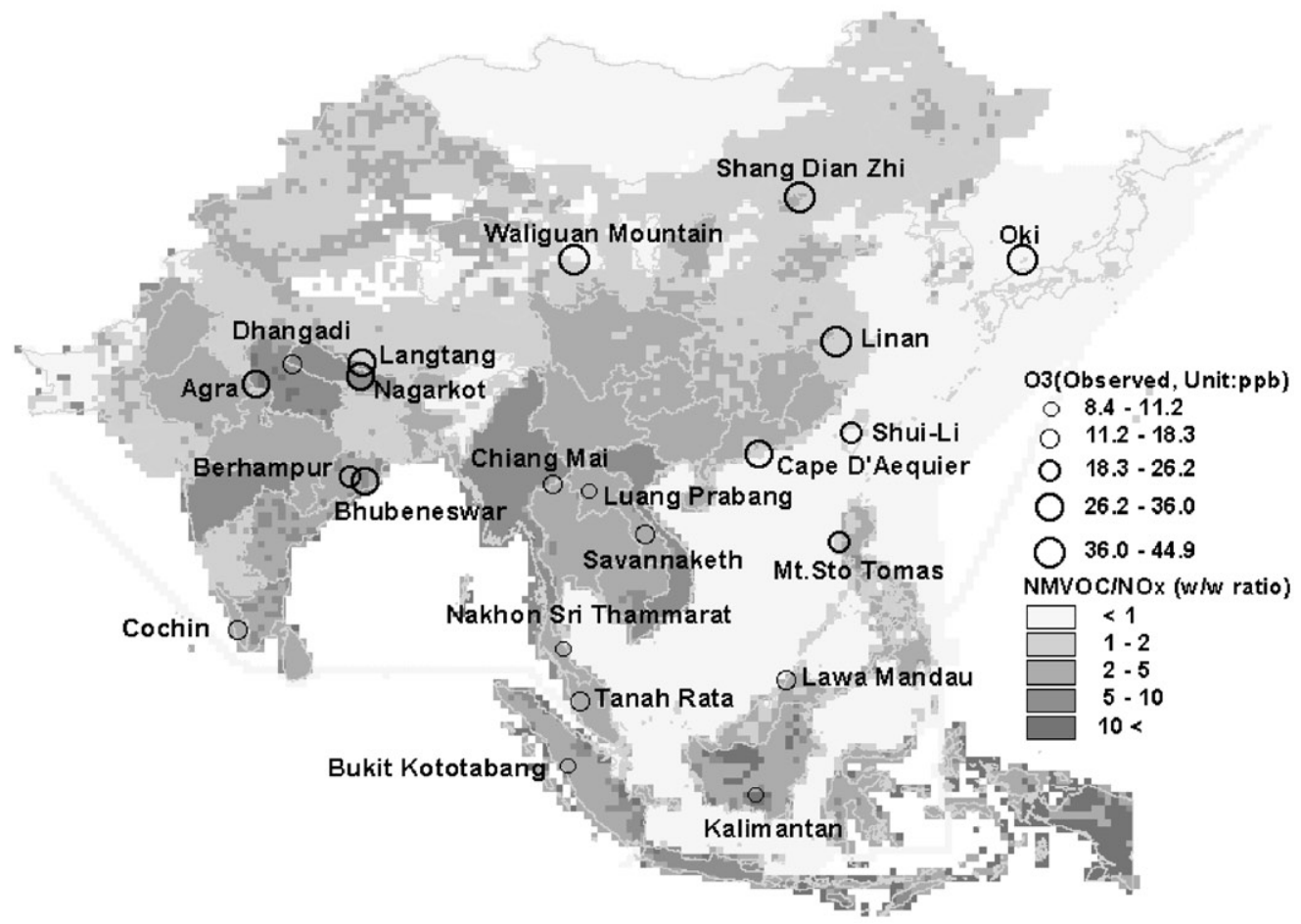

Fig. 8 (continued). 
Linan, China
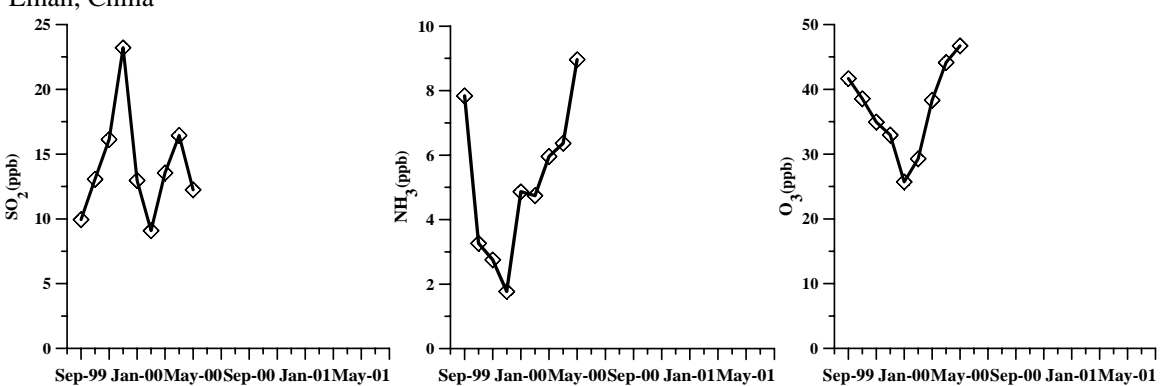

Bhubeneswar, India
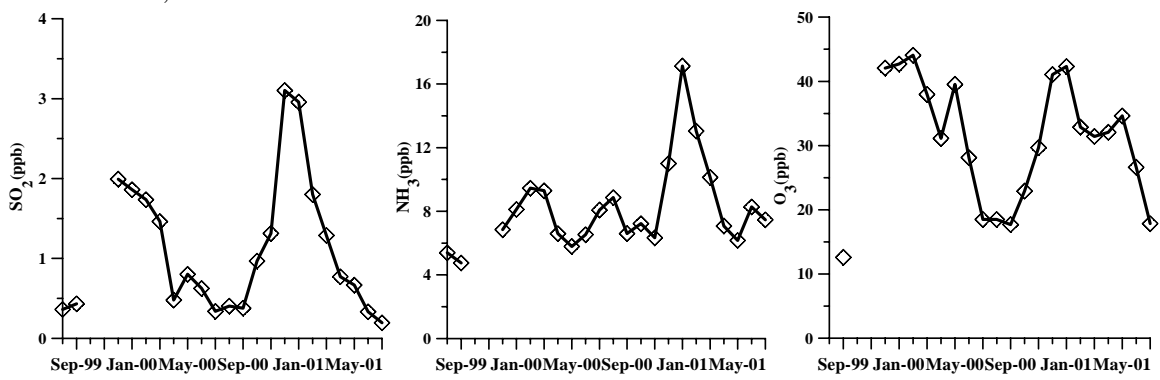

Chiang Mai, Thailand
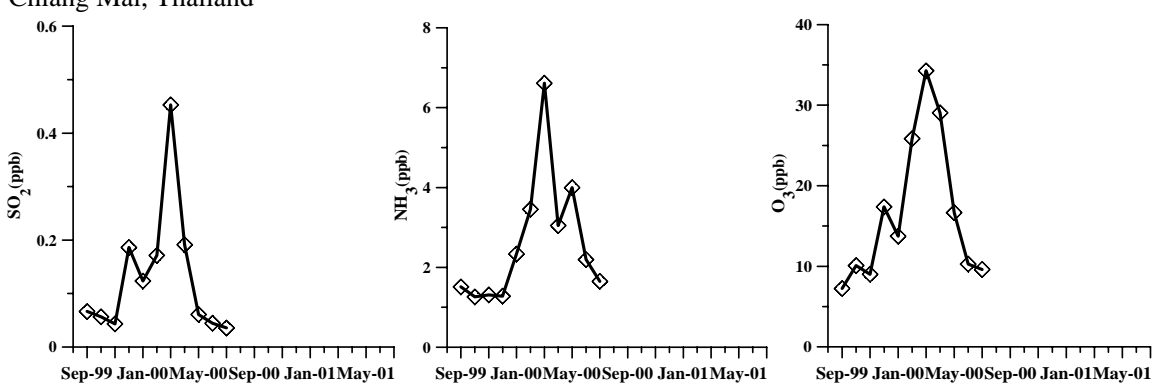

Tamanrasset, Algeria
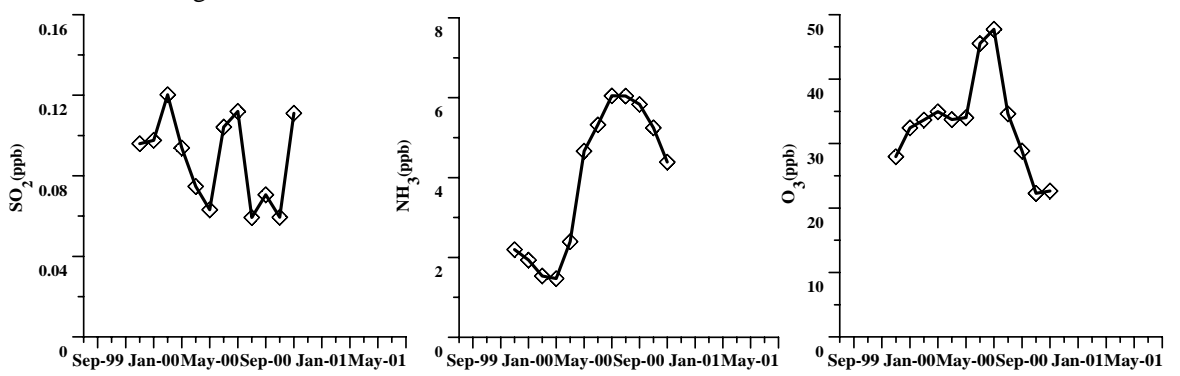

Lamto, Ivory Coast
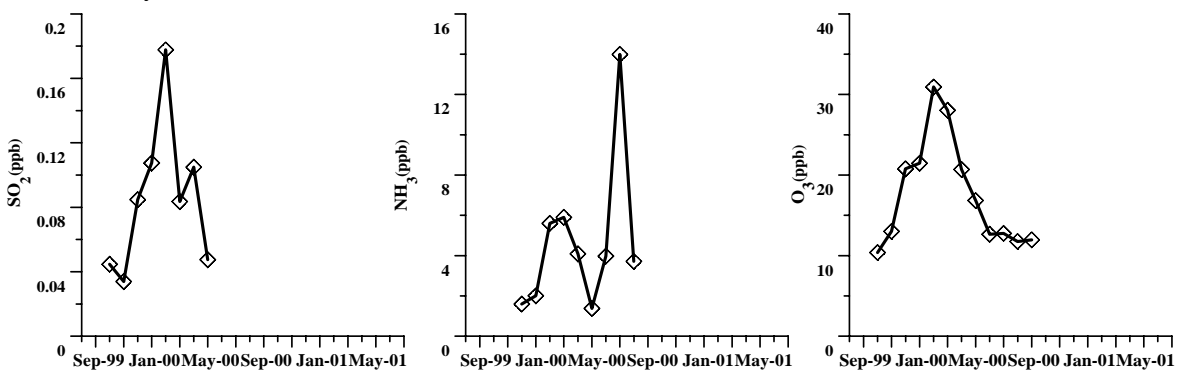

Fig. 9. Seasonal variation in monthly values of $\mathrm{SO}_{2}$ (left), $\mathrm{NH}_{3}$ (middle) and $\mathrm{O}_{3}$ (right) at selected sites. 

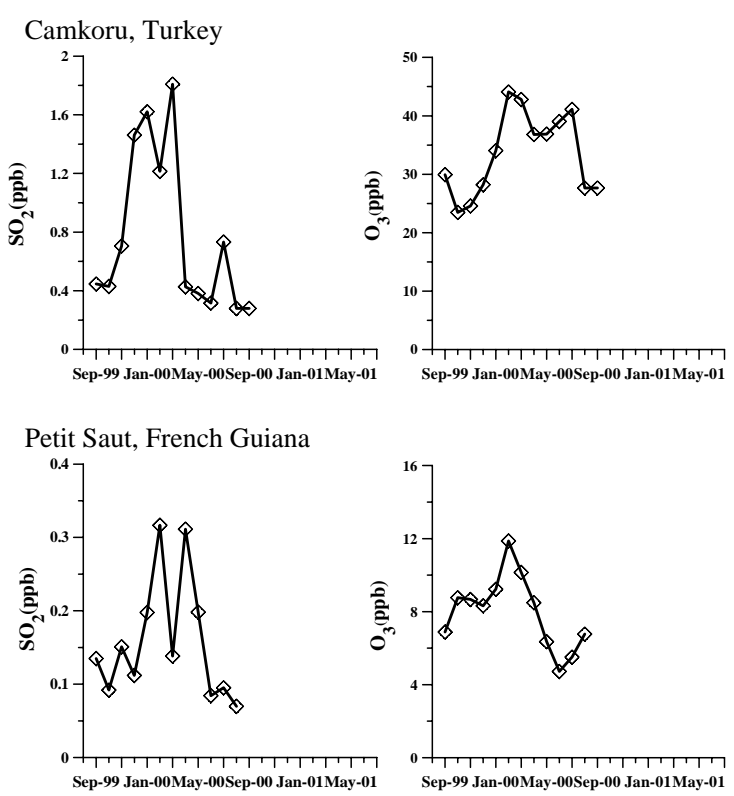

El Tololo, Chile
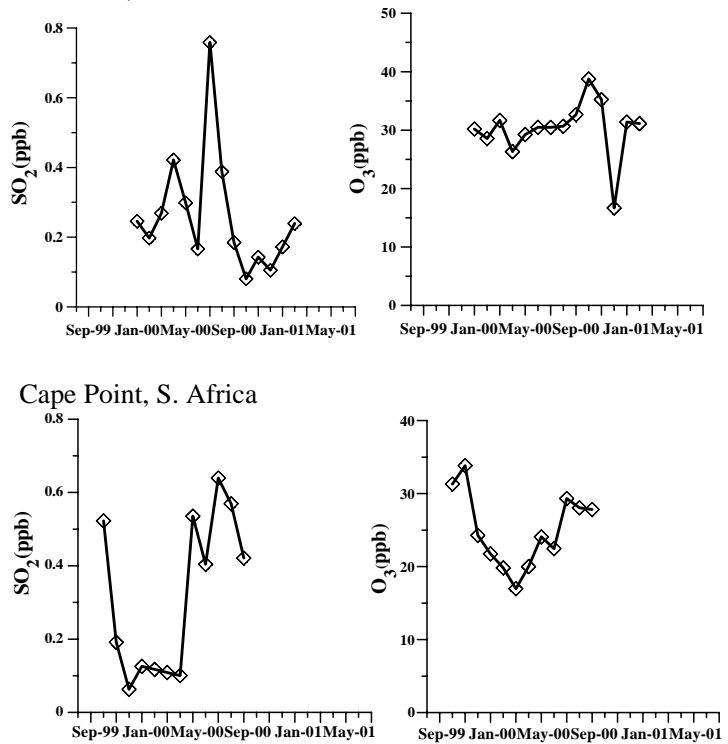

Mt. Sto. Tomas, Philippines
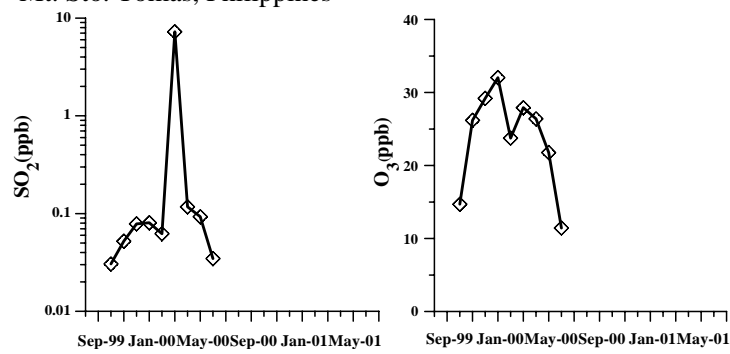

Fig. 10. Seasonal variation in monthly values of $\mathrm{SO}_{2}$ (left), and $\mathrm{O}_{3}$ (right) at selected sites. region-to-region. For example, $\mathrm{SO}_{2}$ in East Asia peaks during the winter season (as illustrated by the data at Linan, China), reflecting an increase in emissions associated with domestic heating in China and a decrease in the rate of the gas-phase loss of $\mathrm{SO}_{2}$ via chemical conversion to sulfate, and decrease in summer in association with increased precipitation and a shift to on-shore flows. The concentrations in Taiwan and Japan show a similar trend, which may be in part a result of long-range transport of $\mathrm{SO}_{2}$ from China. At Linan, the minimum value in $\mathrm{NH}_{3}$ and $\mathrm{O}_{3}$ occurs in winter. In South Asia, the peak $\mathrm{SO}_{2}$ values occur in winter and spring, and decrease dramatically during the summer monsoon season, reflecting the important role that wet removal plays in influencing the seasonal cycle of ambient $\mathrm{SO}_{2}$ levels. A similar cycle occurs for ozone. However, ammonia does not show as distinct a decrease during the monsoon. The measurements at Chiang Mai, Thailand show a pronounced maximum in all the three gases in spring. This reflects the importance of regional scale biomass burning. Distinct seasonal cycles are found at the sites in Africa and South America. These also reflect the interplay between seasonal emissions such as those due to biomass burning, and seasonal meteorological conditions, including dry and wet seasons and major shifts in wind direction.

At a few of the measurement sites in Asia, $\mathrm{SO}_{2}$ was measured in 1994 using the same passive sampler technique (Carmichael et al., 1995). This allows for a comparison of $\mathrm{SO}_{2}$ levels in 1999/2000 with those in 1994. The results are presented in Fig. 11. As illustrated, values in Hong Kong and Thailand show a marked decrease, as do the values at Agra. At other Indian sites, the values are either constant or increased (i.e., at Cochin). These differences are consistent with changes in regional $\mathrm{SO}_{2}$ emissions in Asia. In Hong Kong, China, and parts of Thailand, sulfur emissions have been declining due in part to a decrease in the sulfur content of fuels. In Agra, local efforts to reduce the impact of pollution on the Taj Mahal have led to closure of many small industrial sources. Further details are discussed in Street et al. (2001) and Carmichael et al. (2002).

\section{Conclusions}

Measurements of gaseous $\mathrm{SO}_{2}, \mathrm{NH}_{3}$, and $\mathrm{O}_{3}$ using IVL passive sampler technology were obtained during a pilot measurement program initiated by the WMO/ GAW Urban Research Meteorology and Environment (GURME) project. Monthly measurements were obtained for $1 \mathrm{yr}$ at 36 stations in 12 Asian countries, five African countries, six South American countries, and Turkey. The observed $\mathrm{SO}_{2}$ concentrations varied from a high of $13 \mathrm{ppb}$ at Linan, China, to $<0.03 \mathrm{ppb}$ for four stations. At 30 of 36 regional stations, the observed 


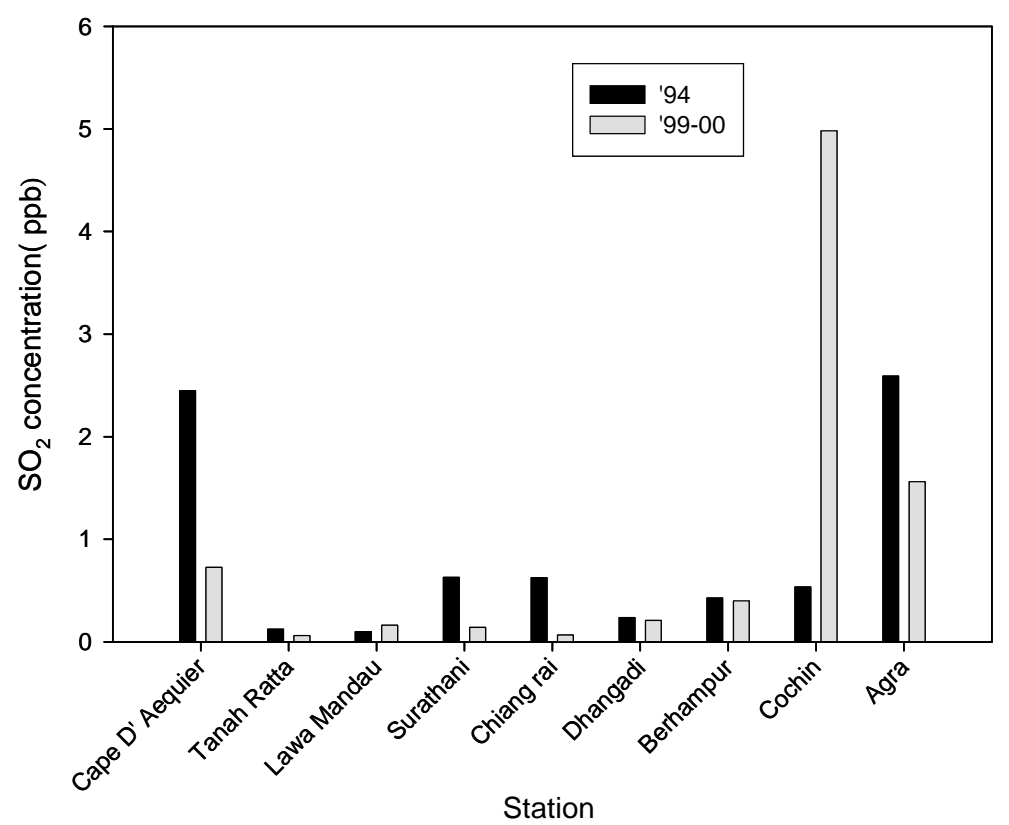

Fig. 11. Changes in annual median $\mathrm{SO}_{2}$ concentrations between 1994 and 1999/2000.

mean annual concentrations were $<1.0 \mathrm{ppb}$. Annual median ammonia concentrations range from $20 \mathrm{ppb}$ at Dhangadi, India, to $<1 \mathrm{ppb}$ for nine stations. At 27 of regional stations, the samples' ambient ammonia levels exceeded $1 \mathrm{ppb}$. The median ozone concentrations varied from a maximum of $45 \mathrm{ppb}$ at Waliguan Mountain to $8 \mathrm{ppb}$ at Petit Saut, French Guiana. In general, the highest ozone values were found in the midlatitudes, with the Northern hemisphere mid-latitude values exceeding the Southern hemisphere mid-latitude levels, and the lowest values were found in the tropical regions.

Results from this study help to demonstrate that diffusive samplers are ideal for measurements at remote sites, for checking transport models, screening studies, mapping concentrations in cities, siting of more advanced stations, personal monitoring, etc. The main advantages are: the samplers are small, silent, do not need electricity; the measurements are made in situ (without inlet tubing); the measurement range is very large; technical personnel are not needed at the sampling site; field calibration is not needed; $100 \%$ time coverage can be obtained, and they are simple to deploy and mail. The drawbacks are that only gases can be monitored, that the results are not obtained immediately, and peak values of short duration are not resolved.

Finally, these results demonstrate that a passive sampler offers a low-cost means of obtaining highquality measurement, covering large regions, while engaging many scientists around the world.

\section{Acknowledgements}

This study was supported in part with funds from the NOAA/US Weather Service through WMO/ GAW_GURME project, the Japan Trust Fund at the World Bank as part of RAINS-Asia Part II and The Swedish Consultancy Fund at the World Bank. We also wish to thank all the individuals and institutes who helped make this project a success.

\section{References}

Ayers, G.P., Keywood, M.D., Gillet, R.W., Manins, P.C., Malfroy, H., Bardsley, T., 1998. Validation of passive diffusion samplers for $\mathrm{SO}_{2}$ and $\mathrm{NO}_{2}$. Atmospheric Environment 32, 3593-3609.

Ayers, G.P., Peng, L.C., Fook, L., Kong, C.W., Gillet, R.W., Manins, P.C., 2000. Atmospheric concentrations and deposition of oxides sulfur and nitrogen species at Petaling Jaya, Malaysia, 1993-1998. Tellus B 52, 60-73.

Ayers, G.P., Peng, L.C., Gillet, R.W., Fook, L., 2002. Rainwater composition and acidity at five sites in Malaysia in 1996. Water, Air and Soil Pollution 133, 15-30.

Carmichael, G.R., Ferm, M., Adikary, S., Ahmed, J., Mohan, M., Hong, M.-S., Chen, L., Fook, L., Liu, C.M., Soedomo, M., Tran, G., Suksomsank, K., Zhao, D., Arndt, R., Chen, L.L., 1995. Observed regional distribution of sulfur dioxide in Asia. Water, Air and Soil Pollution 85, 2289-2294.

Carmichael, G.R., Street, D.G., Calori, G., Amann, M., Jacobson, M.Z., Hansen, J., Ueda, H., 2002. Changing 
trends in sulfur emissions in Asia: Implications for acid deposition, air pollution and climate. Environmental Science and Technology 36 (22), 4707-4713.

Ferm, M., 2001a. The theories behind diffusive sampling. Proceedings from the International Conference on Measuring Air Pollutants by Diffusive Sampling, Montpellier, France, 26-28 September 2001, pp. 31-40.

Ferm, M., 2001b. Validation of a diffusive sampler for ozone in workplace atmospheres according to EN838. Proceedings from the International Conference on Measuring Air Pollutants by Diffusive Sampling, Montpellier, France, 26-28 September 2001, pp. 298-303.

Ferm, M., Rodhe, H., 1997. Measurements of air concentrations of $\mathrm{SO}_{2}, \mathrm{NO}_{2}$ and $\mathrm{NH}_{3}$ at rural and remote sites in Asia. Journal of Atmospheric Chemistry 27, 17-29.

Ferm, M., Svanberg, P.A., 1998. Cost-efficient techniques for urban- and background measurements of $\mathrm{SO}_{2}$ and $\mathrm{NO}_{2}$. Atmospheric Environment 32, 1377-1381.

Gillett, R.W., Ayers, G.P., Mhwe, T., Selleck, P.W., Harjanto, H., 2000. Concentrations of nitrogen and sulfur species in gas and rainwater from several sites in Indonesia. Water, Air and Soil Pollution 120, 205-215.
Kirchner, M., Braeutigam, S., Ferm, M., Haas, M., Hangartner, M., Hofschreuder, P., Kasper-Giebl, A., Römmelt, H., Striedner, J., Terzer, W., Thöni, L., Werner, H., Zimmerling, R., 1999. Field intercomparison of diffusive samplers for measuring ammonia. Journal of Environmental Monitoring 1, 259-265.

Palmes, E.D., Gunnison, A.F., 1973. Personal monitoring device for gaseous contaminants. American Industrial Hygiene Association Journal 34, 78-81.

Sjöberg, K., Lövblad, G., Ferm, M., Ulrich, E., Cecchini, S., Dalstein, L., 2001. Ozone measurements at forest plots using diffusive samplers. Proceedings from the International Conference on Measuring Air Pollutants by Diffusive Sampling, Montpellier, France, 26-28 September 2001, pp. 116-123.

Stevenson, K., Bush, T., Mooney, D., 2001. Five years of nitrogen dioxide measurement with diffusion tube samplers at over 1000 sites in the UK. Atmospheric Environment 35, 281-287.

Street, D.G., Jiang, K., Hu, X., Sinton, J.E., Zhang, X.-Q., $\mathrm{Xu}$, D., Jacobson, M.Z., Hansen, J.E., 2001. Recent reductions in China's greenhouse gas emissions. Science 294, 1835-1837. 